\title{
KEPEMIMPINAN DAN MOTIVASI PENGARUHNYA TERHADAP KEPUASAN KERJA KARYAWAN
}

\author{
Kusnanto Darmawan \\ Program Studi Manajemen, STIE Widya Gama Lumajang \\ kusnanto.wiga@gmail.com
}

\begin{abstract}
The purpose of this study is to determine the influence of leadership and motivation partially and simultaneously to job satisfaction employees CV. Icon Teqnologi. The research type used is descriptive with causal associative approach. This study was conducted with the number of respondents as many as 35 people. The sampling technique used is a saturated sampling technique. Hypothesis testing is done by multiple linear regression analysis for hypothesis through SPSS 16 for windows program. Based on the results obtained in the study that partially influence the leadership of employee job satisfaction, while motivation has no effect on employee job satisfaction. But simultaneously leadership and motivation affect the employee job satisfaction. The amount of influence of leadership and work motivation on employee job satisfaction is shown by the value of determination (R2) of 0.33 while the rest of $67 \%$ influenced by other variables such as discipline, compensation, organizational culture and others.
\end{abstract}

\section{Keywords: Leadership, Motivation, Job Satisfaction}

Abstrak. Tujuan penelitian ini adalah untuk mengetahui pengaruh kepemimpinan dan motivasi secara parsial dan simultan terhadap kepuasan kerja karyawan CV. Icon Teqnologi. Jenis penelitian yang digunakan adalah deskriptif dengan pendekatan asosiatif kausal. Penelitian ini dilakukan dengan jumlah responden sebanyak 35 orang. Teknik pengambilan sampel yang digunakan adalah teknik sampling jenuh. Pengujian hipotesis dilakukan dengan analisis regresi linier berganda untuk hipotesis melalui program SPSS 16 for windows. Berdasarkan hasil penelitian di peroleh bahwa secara parsial kepemimpinan berpengaruh terhadap kepuasan kerja karyawan, sedangkan motivasi tidak berpengaruh terhadap kepuasan kerja karyawan. Namun secara simultan kepemimpinan dan motivasi berpengaruh terhadap kepuasan kerja karyawan. Besarnya pengaruh kepemimpinan dan motivasi kerja terhadap kepuasan kerja karyawan ditunjukan oleh nilai determinasi $\left(R^{2}\right)$ sebesar 0,33 sedangkan sisanya sebesar $67 \%$ dipengaruhi oleh variabel lain seperti kedisiplinan, kompensasi, budaya organisasi dan lain-lain.

\section{Kata Kunci : Kepemimpinan, Motivasi, Kepuasan Kerja}

\section{PENDAHULUAN}

Manusia memegang peran yang penting dalam semua proses kehidupan, karena manusia sangat pemikir, perencanaan, sekaligus pelaksanaan segala kegiatan. Oleh karena itu manusia merupakan salah satu sumber daya, yaitu sumber daya manusia, sumber daya alam, dan sumber daya capital. Untuk mencapai tujuan yang diinginkan, perusahaan perlu melakukan manajemen sumber daya yang baik. Manajemen sumber daya manusia perlu dilakukan agar sumber daya manusia potensial yang dimiliki perusahaan dapat diarahkan secara efektif dan efisien.

Kepemimpinan merupakan faktor penting dalam memberikan pengarahan kepada karyawan apalagi pada saat-saat sekarang ini di mana semua serba terbuka, 
maka kepemimpinan yang dibutuhkan adalah kepemimpinan yang bisa memberdayakan karyawannya. Kepemimpinan yang bisa menumbuhkan motivasi kerja karyawan adalah kepemimpinan yang bisa menumbuhkan rasa percaya diri para karyawan dalam menjalankan tugasnya masing-masing. Kepemimpinan merupakan kemampuan untuk mempengaruhi pihak lain. Keberhasilan seorang pemimpin tergantung kepada kemampuannya untuk mempengaruhi itu. Dengan kata lain kepemimpinan dapat diartikan sebagai kemampuan seseorang untuk mempengaruhi orang lain, melalui komunikasi baik langsung maupun tidak langsung dengan maksud untuk menggerakkan orang-orang tersebut agar dengan penuh pengertian, kesadaran dan senang hati bersedia mengikuti kehendak pemimpin. Seorang pemimpin yang efektif adalah seorang yang memiliki kemampuan tersebut (Anoraga,2003:2)

Motivasi merupakan hal yang sangat penting untuk diperhatikan oleh pihak manajemen bila mereka menginginkan setiap karyawan dapat memberikan kontribusi positif terhadap pencapaian tujuan perusahaan. Karena dengan motivasi, seorang karyawan akan memiliki semangat yang tinggi dalam melaksanakan tugas yang dibebankan kepadanya. Tanpa motivasi, seorang karyawan tidak dapat memenuhi tugasnya sesuai standar atau bahkan melampaui standar karena apa yang menjadi motif dan motivasinya dalam bekerja tidak terpenuhi. Sekalipun seorang karyawan memiliki kemampuan operasional yang baik bila tidak memiliki motivasi dalam bekerja, hasil akhir dari pekerjaannya tidak akan memuaskan.

Kepuasan kerja adalah keadaan emosional yang menyenangkan atau tidak menyenangkan dengan mana karyawan memandang pekerjaan mereka. Kepuasan kerja mencerminkan perasaan seseorang terhadap pekerjaan mereka, yang biasanya tampak dalam sikap positif para karyawan terhadap pekerjaan dan segala sesuatu yang dihadapi dilingkungan kerjanya (Handoko, 2001). Kepuasan kerja mengekspresikan sejumlah kesesuaian antara harapan seseorang tentang pekerjaannya yang dapat berupa prestasi kerja yang diberikan oleh perusahaan dan imbalan yang diberikan atas pekerjaannya. Pada hakekatnya seseorang didorong untuk beraktivitas karena dia berharap bahwa hal tersebut akan membawa keadaan yang lebih baik memuaskan dari pada keadaan sekarang. Jadi bekerja adalah suatu bentuk aktivitas yang bertujuan untuk mendapatkan kepuasan kerja (Smith dan Weckelly dalam As'ad 2004).

Obyek pada penelitian ini adalah karyawan CV. ICON Lumajang. Tujuan penelitian ini adalah untuk mengetahui pengaruh kepemimpinan dan motivasi secara parsial dan simultan terhadap kepuasan kerja karyawan.

\section{KAJIAN TEORI \\ Kepemimpinan}

Kepemimpinan memegang peran yang sangat penting di dalam sebuah organisasi. Tanpa adanya sosok pemimpin, suatu organisasi akan sulit untuk mencapai visi dan misinya. Menurut Kartono (2008), pemimpin adalah seorang pribadi yang memiliki kecakapan dan kelebihan khususnya di satu bidang, sehingga dia mampu mempengaruhi orang-orang lain untuk bersama-sama melakukan aktivits-aktivitas tertentu, demi pencapaian satu atau beberapa tujuan. pemimpin adalah merupakan inisiator, motivator, stimulator, dinamisator, dan inovator dalam organisasi. Menurut Kartono, kepemimpinan merupakan kekuatan aspirasional, kekuatan semangat, dan kekuatan moral yang kreatif, yang mampu mempengaruhi para anggota untuk mengubah sikap, sehingga mereka menjadi conform dengan keinginan pemimpin.

Menurut Wahjosumidjo (1991:154) secara garis besar indikator kepemimpinan adalah sebagai berikut: 
a. Bersifat adil. Dalam kegiatan suatu organisasi, rasa kebersamaan diantara para anggota adalah mutlak, sebab rasa kebersamaan pada hakikatnya merupakan pencerminan dari pada kesepakatan antara para bawahan maupun antara pemimpin dengan bawahan dalam mencapai tujuan organisasi

b. Memberi sugesti. Sugesti biasanya disebut sebagai saran atau anjuran. Dalam rangka kepemimpinan, sugesti merupakan pengaruh dan sebagainya, yang mampu menggerakkan hati orang lain dan sugesti mempunyai peranan yang sangat penting di dalam memelihara dan membina harga diri serta rasa pengabdian, partisipasi, dan rasa kebersamaan diantara para bawahan.

c. Mendukung tujuan. Tercapainya tujuan organisasi tidak secara otomatis terbentuk, melainkan harus didukung oleh adanya kepemimpinan. Oleh karena itu, agar setiap organisasi dapat efektif dalam arti mampu mencapai tujuan yang telah ditetapkan, maka setiap tujuan yang ingin dicapai perlu disesuaikan dengan keadaan organisasi serta memungkinkan para bawahan untuk bekerja sama.

d. Katalisator. Seorang pemimpin dikatakan berperan sebagai katalisator, apabila pemimpin itu selalu dapat meningkatkan segala sumber daya manusia yang ada, berusaha memberikan reaksi yang menimbulkan semangat dan daya kerja cepat semaksimal mungkin.

e. Menciptakan rasa aman Setiap pemimpin berkewajiban menciptakan rasa aman bagi para bawahannya. Dan ini hanya dapat dilaksanakan apabila setiap pemimpin mampu memelihara hal-hal yang positif, sikap optimisme di dalam menghadapi segala permasalahan, sehingga dalam melaksanakan tugas-tugasnya, bawahan merasa aman, bebas dari segala perasaan gelisah, kekhawatiran, merasa memperoleh jaminan keamanan dari pimpinan.

f. Sebagai wakil organisasi. Setiap bawahan yang bekerja pada unit organisasi apapun, selalu memandang atasan atau pimpinannya mempunyai peranan dalam segala bidang kegiatan, lebih-lebih yang menganut prinsip-prinsip keteladanan atau panutan-panutan. Seorang pemimpin adalah segalasegalanya, oleh karena itu segala perilaku, perbuatan, dan kata- katanya akan selalu memberikan kesan-kesan tertentu terhadap organisasinya.

g. Sumber inspirasi. Seorang pemimpin pada hakikatnya adalah sumber semangat bagi para bawahannya. Oleh karena itu, setiap pemimpin harus selalu dapat membangkitkan semangat para bawahan sehingga bawahan menerima dan memahami tujuan organisasi dengan antusias dan bekerja secara efektif ke arah tercapainya tujuan organisasi.

h. Bersikap menghargai. Setiap orang pada dasarnya menghendaki adanya pengakuan dan penghargaan diri pada orang lain. Demikian pula setiap bawahan dalam organisasi memerlukan adanya pengakuan dan penghargaan dari atasan. Oleh karena itu, menjadi suatu kewajiban bagi pemimpin untuk mau memberikan penghargaan atau pengakuan dalam bentuk apapun kepada bawahannya.

\section{Motivasi}

Dalam kehidupan organisasi, pemberian dorongan sebagai bentuk motivasi kerja terhadap bawahan atau karyawan penting dilakukan untuk meningkatkan kinerja. Menurut Robbins dan Coulter (2014:458), motivasi adalah kerelaan untuk melakukan usaha-usaha tingkat tinggi guna mencapai tujuan-tujuan organisasi, dipersaratkan oleh kemampuan usaha tadi untuk memuaskan kebutuhan individu tertentu. 
Indikator motivasi kerja dalam penelitian ini menggunakan teori dari Herzberg dalam Slamet (2007: 137) yaitu:

a. Hubungan dengan rekan kerja dan atasan. Suasana harmonis antar pegawai terjalin di tempat kerja dan selalu terjalin kerjasama bawahan dengan atasan maupun dengan rekan kerja.

b. Lingkungan kerja. Terdapat fasilitas penunjang pekerjaan yang memadai sesuai dengan kebutuhan kerja dan suasana kerja yang sesuai dengan yang di harapkan.

c. Kesempatan meningkatkan pengetahuan dan keterampilan. Perusahaan/ organisasi selalu memberikan pendidikan dan pelatihan bagi pegawainya.

d. Pemberian tunjangan. Perusahaan/organisasi telah memberikan tunjangan yang layak bagi pegawainya.

\section{Kepuasan Kerja}

Setiap orang yang bekerja mengharapkan memperoleh kepuasan dari tempatnya bekerja. Pada dasarnya kepuasan kerja merupakan hal yang bersifat individual karena setiap individu akan memiliki tingkat kepuasan yang berbedabeda sesuai dengan nilai-nilai yang berlaku dalam diri setiap individu. Semakin banyak aspek dalam pekerjaan yang sesuai dengan keinginan individu, maka semakin tinggi tingkat kepuasan yang dirasakan. Menurut Robbins $(2003 ; 78)$ kepuasan kerja adalah "sikap umum terhadap pekerjaan seseorang yang menunjukkan perbedaan antara jumlah penghargaan yag diterima pekerja dan jumlah yang mereka yakini seharusnya mereka terima".

Selain penyebab kepuasan kerja, ada juga faktor penentu kepuasan kerja. Diantaranya adalah sebagi berikut :

a. Pekerjaan itu sendiri (work it self). Setiap pekerjaan memerlukan suatu keterampilan tertentu sesuai dengan bidangnya masing-masing. Sukar tidaknya suatu pekerjaan serta perasaan seseorang bahwa keahliannya dibutuhkan dalam melakukan pekerjaan tersebut, akan meningkatkan atau mengurangi kepuasan.

b. Hubungan dengan atasan (supervision). Kepemimpinan yang konsisten berkaitan dengan kepuasan kerja adalah tenggang rasa (consideration). Hubungan fungsional mencerminkan sejauhmana atasan membantu tenaga kerja untuk memuaskan nilai-nilai pekerjaan yang penting bagi tenaga kerja. Hubungan keseluruhan didasarkan pada ketertarikan antar pribadi yang mencerminkan sikap dasar dan nilai-nilai yang serupa, misalnya keduanya mempunyai pandangan hidup yang sama. Tingkat kepuasan kerja yang paling besar dengan atasan adalah jika kedua jenis hubungan adalah positif. Atasan yang memiliki ciri pemimpin yang transformasional, maka tenaga kerja akan meningkat motivasinya dan sekaligus dapat merasa puas dengan pekerjaannya.

c. Teman sekerja (workers). Teman kerja merupakan faktor yang berhubungan dengan hubungan antara pegawai dengan atasannya dan dengan pegawai lain, baik yang sama maupun yang berbeda jenis pekerjaannya.

d. Promosi (promotion). Promosi merupakan faktor yang berhubungan dengan ada tidaknya kesempatan untuk memperoleh peningkatan karier selama bekerja.

e. Gaji atau upah (pay). Merupakan faktor pemenuhan kebutuhan hidup pegawai yang dianggap layak atau tidak. 


\section{METODE PENELITIAN}

Penelitian ini menggunakan penelitian kuantitatif dengan mencari hubungan assosiatif yang bersifat kausal. Menurut Sugiyono (2013:11), "Penelitian assosiatif merupakan penelitian yang bertujuan untuk mengetahui hubungan dua variabel atau lebih". Sedangkan kausal adalah hubungan sebab akibat. Dalam penelitian ini populasinya adalah semua karyawan CV. ICON Lumajang. Teknik pengambilan sampel yang digunakan dalam penelitian ini diambil Non Probability Sampling. "Non Probability Sampling merupakan pengambilan sampel yang tidak memberi peluang/kesempatan sama bagi setiap unsur atau anggota populasi untuk dipilih menjadi sampel" (Sugiyono, 2014:218). Dan teknik yang dipilih yaitu Sampling jenuh. "Sampling jenuh adalah teknik penentuan sampel bila semua anggota populasi digunakan sebagai sampel" (Sugiyono, 2015:126).

\section{Teknik Analisis Data}

Sesuai dengan hipotesis dan tujuan yang ingin dicapai dalam penelitian, maka digunakan analisis regresi linier berganda dengan bentuk hubungan assosiatif kausal, yang digunakan untuk mengetahui pengaruh variabel independen dalam memprediksi variabel dependen dalam penelitian ini (Sugiyono, 2013:169). Sebelum melakukan analisis dan uji pengaruh, maka terhadap kuesioner perlu dilakukan uji validitas dan reliabilitas. Selanjutnya akan dilakukan analisis dan uji pengaruh yang menggunakan asumsi dasar regresi linier berganda bahwa data harus berdistribusi normal.

\section{Pengujian Hipotesis}

Setelah dilakukan analisis regresi linier berganda kemudian dilakukan pengujian hipotesis yaitu uji t (uji parsial) dan uji F (uji simultan) yang digunakan untuk mengetahui apakah ada pengaruh antara variabel independen (persepsi labelisasi halal dan harga) terhadap variabel dependen (keputusan pembelian). Serta manakah diantara variabel independen yang mempunyai dominan terhadap variabel dependen. Selanjutnya dilakukan Uji Koefisien Determinasi $\left(R^{2}\right)$ yang digunakan untuk mengetahui tingkat ketepatan yang paling baik dalam analisa regresi. Tingkat ketepan dalam koefisien determinasi itu biasanya dinyatakan dalam prosentase.

\section{HASIL DAN PEMBAHASAN \\ Deskripsi Responden}

Responden dalam penelitian ini adalah Karyawan Icon Technology Lumajang. Adapun jumlah responden yang diambil sebanyak 35 orang. Dalam bagian ini responden dibagi berdasarkan kelompok jenis kelamin. Dari data menunjukkan bahwa dari 35 responden dapat diketahui yaitu: 23 orang atau 66\% diantaranya adalah laki-laki dan sisanya sebanyak 12 orang atau $34 \%$ adalah perempuan. Jumlah data tersebut menunjukkan bahwa yang mendominasi di Icon Technology Lumajang adalah karyawan laki-laki.

Dalam bagian ini responden dibagi berdasarkan kelompok usia. Berdasarkan deskripsi responden dengan rentangan usia antara 17 - 21 Tahun adalah sebanyak 11 orang atau sebesar $32 \%$, sedangkan untuk responden dengan rentangan usia antara 22 - 26 Tahun adalah sebanyak 18 orang atau sebesar 51\% dan untuk responden dengan rentangan usia antara $>27$ Tahun adalah sebanyak 6 orang atau sebesar $17 \%$. Dengan demikian dapat disimpulkan bahwa responden di dalam penelitian ini didominasi oleh karyawan dengan rentangan usia antara $22-26$ Tahun. 


\section{Deskripsi Tanggapan Responden Terhadap Variabel Penelitian}

Hasil tanggapan responden terhadap variabel kepemimpinan (X1), motivasi $\left(\mathrm{X}_{2}\right)$ dan Kepuasan Kerja (Y). Dapat ditarik kesimpulan bahwa nilai rata-rata menunjukkan penilaian terhadap variabel kepemimpinan, motivasi dan kepuasan kerja mempunyai kecenderungan nilai cukup tinggi, ini menunjukkan bahwa kepemimpinan, motivasi dan kepuasan kerja merupakan hal yang penting bagi responden dalam hal ini adalah karyawan Icon Technology Lumajang.

\section{Hasil Analisis Data \\ Hasil Pengujian Validitas}

Dari data penelitian yang menggunakan kuesioner dapat diketahui besarnya koefisien korelasi dari seluruh butir pertanyaan yang terdiri dari masing-masing 8 (delapan) butir pertanyaan untuk variabel kepemimpinan (X1), 4 (empat) butir pertanyaan untuk variabel motivasi (X2), 10 (sepuluh) butir pertanyaan untuk variabel kepuasan kerja (Y). Dari hasil perhitungan koefisien korelasi, seluruhnya mempunyai $r$ hitung yang lebih besar dari $r$ minimal $(0,3)$. Dengan demikian bahwa seluruh butir pertanyaan dinyatakan valid. Kesimpulannya seluruh butir pertanyaan yang ada pada instrumen penelitian dapat dinyatakan layak sebagai instrumen penelitian karena dapat menggali data atau informasi yang diperlukan.

\section{Hasil Pengujian Reliabilitas}

Berdasarkan rekapitulasi hasil uji reabilitas menunjukkan koefisien reliabilitas Cronbach's Alpha untuk variabel kepemimpinan ( $\left.\mathrm{X}_{1}\right)$ sebesar 0,625, variabel motivasi $\left(\mathrm{X}_{2}\right)$ sebesar 0,836 dan variabel kepuasan kerja $(\mathrm{Y}$ ) sebesar 0,904. Jadi dapat disimpulkan bahwa kuesioner yang digunakan untuk mengukur variabel kepemimpinan $\left(\mathrm{X}_{1}\right)$, motivasi $\left(\mathrm{X}_{2}\right)$ dan kepuasan kerja $(\mathrm{Y})$ adalah reliabel, sehingga kuesioner yang digunakan adalah kuesioner yang handal karena dapat memberikan hasil yang tidak berbeda jika dilakukan pengukuran kembali terhadap subjek yang sama pada waktu yang berlainan.

\section{Uji Asumsi Dasar Regresi Linier Berganda}

\section{Tabel 1}

Coefficients ${ }^{\mathrm{a}}$

\begin{tabular}{|c|c|c|c|c|c|c|c|}
\hline \multirow[b]{2}{*}{ Model } & \multicolumn{2}{|c|}{$\begin{array}{l}\text { Unstandardized } \\
\text { Coefficients }\end{array}$} & \multirow{2}{*}{\begin{tabular}{|c|}
$\begin{array}{c}\text { Standardize } \\
\mathrm{d} \\
\text { Coefficients }\end{array}$ \\
Beta
\end{tabular}} & \multirow[b]{2}{*}{$\mathrm{t}$} & \multirow[b]{2}{*}{ Sig. } & \multicolumn{2}{|c|}{$\begin{array}{c}\text { Collinearity } \\
\text { Statistics }\end{array}$} \\
\hline & B & Std. Error & & & & $\begin{array}{c}\text { Toleranc } \\
\mathrm{e}\end{array}$ & VIF \\
\hline $\begin{array}{ll}1 & \text { (Constan } \\
\text { t) }\end{array}$ & 16.097 & 7.910 & & 2.035 & .050 & & \\
\hline $\mathrm{X} 1$ & .822 & .215 & .570 & 3.827 & .001 & .944 & 1.059 \\
\hline $\mathrm{X} 2$ & .040 & .316 & .019 & .126 & .900 & .944 & 1.059 \\
\hline
\end{tabular}

a. Dependent Variable: $Y$

Sumber : Hasil Pengolahan SPSS Tahun 2017 


\section{Uji Normalitas}

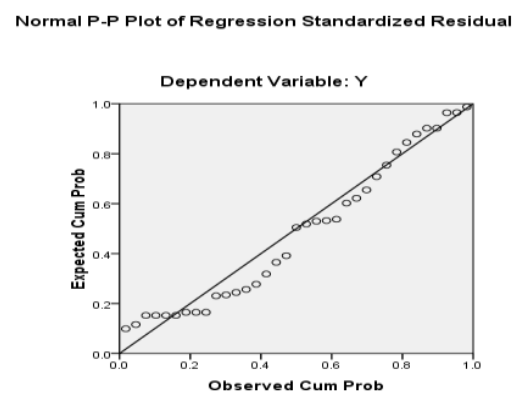

Hasil pengujian tersebut menunjukkan bahwa titik-titik berada tidak jauh dari garis diagonal, hal ini berarti bahwa model regresi tersebut sudah berdistribusi normal.

\section{Uji Multikolinieritas}

Hasil pengujian menunjukkan bahwa semua variabel yang digunakan sebagai prediktor model regresi menunjukkan nilai VIF yang cukup kecil, dimana semuanya berada di bawah 10 dan nilai tolerance lebih dari 0,1 . Hal ini berarti bahwa variabel independen yang digunakan dalam penelitian tidak menunjukkan adanya gejala multikolinieritas, jadi semua variabel independen dalam penelitian ini adalah variabel yang saling independen, sehingga dapat dilanjutkan dalam pengujian regresi linier berganda.

\section{Uji Heteroskedastisitas}

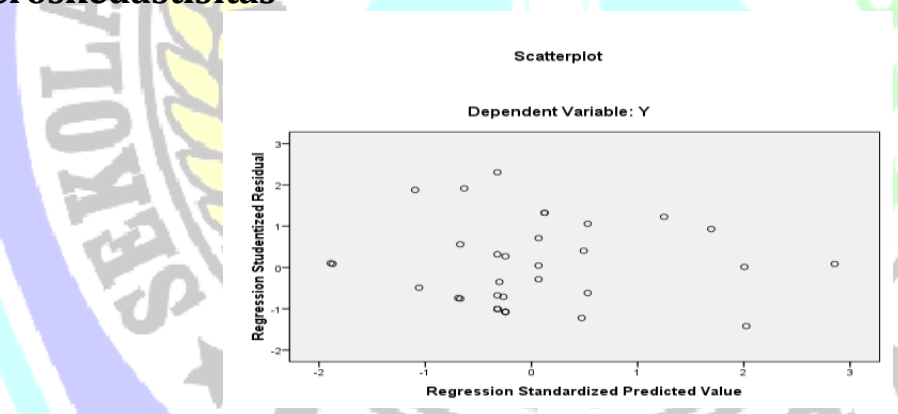

Berdasarkan gambar dapat dilihat bahwa hasil pengujian heteroskedastisitas menunjukkan tidak terdapat pola yang jelas dari titik-titik tersebut. Hal ini menunjukkan bahwa model regresi tidak memiliki gejala adanya heteroskedastisitas, yang berarti tidak ada gangguan yang berarti dalam model regresi ini.

\section{Fungsi Regresi Linier Berganda Yang Dihasilkan}

Model persamaan regresi yang dapat dituliskan dari hasil tersebut dalam bentuk persamaan regresi Unstandardized coefficients adalah sebagai berikut :

$$
\mathrm{Y}=16,097+0,822 \mathrm{X}_{1}+0,040 \mathrm{X}_{2}
$$

"Untuk mengetahui variabel independen yang dominan pengaruhnya terhadap variabel dependen, ditunjukkan dengan koefisien regresi $(\beta)$ yang sudah distandarisasi yaitu nilai beta" (Sutanto Priyo Hastono, 2006:6). Jadi berdasarkan tabel 4.17 di atas, diketahui bahwa variabel bebas yang paling berpengaruh terhadap kepuasan kerja adalah variabel kepemimpinan dengan koefisien 0,822. 


\section{Hasil Pengujian Hipotesis \\ Hasil Uji t (Uji Parsial)}

Hasil uji $t$ untuk variabel $X_{1}$ (kepemimpinan) diperoleh nilai $t$ hitung $=3,827$ dengan tingkat signifikani 0,001. Dengan menggunakan batas signifikansi 0,05 didapat $t$ tabel sebesar $\pm 1,692$. Ini berarti $t_{\text {hitung }}>t_{\text {tabel }}$, maka $\mathrm{H}_{0}$ ditolak dan Ha diterima. Dengan demikian, hipotesis pertama dapat diterima. Dengan kata lain kemimpinan berpengaruh terhadap kepuasan kerja karyawan Icon Technology Lumajang.

Hasil uji $\mathrm{t}$ variabel $\mathrm{X}_{2}$ (motivasi) diperoleh nilai $\mathrm{t}$ hitung $=0,126$ dengan tingkat signifikansi 0,900. Dengan menggunakan batas signifikansi 0,05 didapat $\mathrm{t}$ tabel sebesar $\pm 1,692$. Ini berarti $-\mathrm{t}_{\text {tabel }} \leq \mathrm{t}_{\text {hitung }} \leq \mathrm{t}_{\text {tabel }}$, maka $\mathrm{H}_{0}$ diterima dan Ha ditolak. Dengan demikian maka, hipotesis kedua tidak dapat diterima, yang berarti bahwa motivasi tidak memiliki pengaruh terhadap kepuasan kerja karyawan Icon Technology Lumajang.

\section{Hasil Uji F (Uji Simultan)}

Tabel 2

ANOVA $^{b}$

\begin{tabular}{|ll|r|r|r|r|r|}
\hline \multicolumn{2}{|l|}{ Model } & \multicolumn{1}{|c|}{$\begin{array}{c}\text { Sum of } \\
\text { Squares }\end{array}$} & Df & Mean Square & F & Sig. \\
\hline 1 & Regression & 152.899 & 2 & 76.449 & 7.885 & $.002^{\mathrm{a}}$ \\
& Residual & 310.244 & 32 & 9.695 & & \\
& Total & 463.143 & 34 & & & \\
\hline
\end{tabular}

a. Predictors: (Constant), X2, X1

b. Dependent Variable: $Y$

\section{Sumber : Hasil Pengolahan SPSS Tahun 2017}

Berdasarkan tabel 4.18. dapat diketahui nilai $\mathrm{F}$ hitung sebesar 7,885 lebih besar dari $\mathrm{F}$ tabel 3,29 dengan tingkat signifikasi $0,002<0,05$. Sehingga dapat diketahui terdapat pengaruh kepemimpinan dan motivasi secara simultan signifikan terhadap kepuasan kerja pada karyawan Icon Technology Lumajang.

Berdasarkan uraian tersebut bahwa ada hubungan positif signifikan antara variabel kepemimpinan dan motivasi terhadap kepuasan kerja pada karyawan Icon Technology Lumajang. Dengan demikian secara simultan terdapat pengaruh secara positif yang signifikan variabel kepemimpinan dan motivasi terhadap kepuasan kerja pada karyawan Icon Technology Lumajang.

\section{Uji Koefisien Determinasi $\left(\mathrm{R}^{2}\right)$}

Tabel 3

Model Summaryb

\begin{tabular}{|l|c|r|r|r|}
\hline Model & $\mathrm{R}$ & R Square & $\begin{array}{c}\text { Adjusted R } \\
\text { Square }\end{array}$ & $\begin{array}{r}\text { Std. Error of } \\
\text { the Estimate }\end{array}$ \\
\hline 1 & $.575^{\mathrm{a}}$ & .330 & .288 & 3.11370 \\
\hline
\end{tabular}

a. Predictors: (Constant), X2, X1

b. Dependent Variable: $Y$

\section{Sumber : Hasil Pengolahan SPSS Tahun 2017}


Dari hasil perhitungan dengan menggunakan program SPSS versi 16 dapat diketahui bahwa koefissien determinasi (adjusted $R^{2}$ ) yang diperoleh sebesar 0,330. Hal ini berarti 33\% kepuasan kerja dapat dijelaskan oleh kepemimpinan dan motivasi, sedangkan sisanya yaitu 67\% kepuasan kerja dipengaruhi oleh variabel lainnya yang tidak diteliti dalam penelitian ini.

\section{Pembahasan \\ Pengaruh kepemimpinan terhadap kepuasan kerja}

Kepemimpinan berpengaruh terhadap kepuasan kerja pada karyawan Icon Technology Lumajang, dikarenakan indikator kepemimpinan seperti yang tercantum pada instrumen penelitian yaitu: bersifat adil, member sugesti, mendukung tujuan, katalisator, menciptakan rasa aman, sebagai wakil organisasi, sumber inspirasi, dan bersikap menghargai sudah sesuai sebagai poin untuk meningkatkan kepuasan kerja pada karyawan Icon Technology Lumajang. Dari hasil kuisioner dapat diketahui bahwa pada variabel kepemimpinan memiliki rata-rata jawaban tertinggi 4,29 pada pernyataan "Pimpinan memberikan kesempatan pada semua karyawan untuk mengikuti seleksi jenjang kepegawaian sesuai dengan potensi yang dimiliki karyawan.". Pernyataan ini sesuai dengan pendapat Wahjosumidjo (1991:154), "Dalam kegiatan suatu organisasi, rasa kebersamaan diantara para anggota adalah mutlak, sebab rasa kebersamaan pada hakikatnya merupakan pencerminan dari pada kesepakatan antara para bawahan maupun antara pemimpin dengan bawahan dalam mencapai tujuan organisasi". Sehingga apabila kepemimpinan dapat memberikan kepuasan kepada karyawan maka karyawan akan mengerjakan tugasnya dengan baik demi kemajuan Icon Technology Lumajang.

Indikator kepemimpinan lainnya yaitu mendukung tujuan, sudah sesuai di Icon Technology Lumajang. Hal ini terbukti bahwa kepemimpinan di Icon Technology tercapainya tujuan organisasi tidak secara otomatis terbentuk, melainkan harus didukung oleh adanya kepemimpinan. Oleh karena itu, agar setiap organisasi dapat efektif dalam arti mampu mencapai tujuan yang telah ditetapkan, maka setiap tujuan yang ingin dicapai perlu disesuaikan dengan keadaan organisasi serta memungkinkan para bawahan untuk bekerja sama.

Sehingga kepemimpinan adalah proses mempengaruhi, menggerakkan, mengarahkan, mendorong, dan mengajak orang lain untuk bekerja sama dan mau bekerja secara produktif guna pencapaian tujuan tertentu, sehingga indikator yang digunakan dalam variabel kepemimpinan adalah menggunakan teori dari Wahjosumidjo yaitu: bersifat adil, memberi sugesti, mendukung tercapainya tujuan, sebagai katalisator, menciptakan rasa aman, sebagai wakil organisasi, sumber inspirasi, dan bersikap menghargai.

Dari pendapat di atas dapat ditarik kesimpulan bahwa kepemimpinan dapat berjalan dengan baik dan dapat mempengaruhi karyawan, apabila seorang pemimpin dapat bersifat adil, memberi sugesti, mendukung tercapainya tujuan, sebagai katalisator, menciptakan rasa aman, sebagai wakil organisasi, sumber inspirasi, dan bersikap menghargai.

\section{Pengaruh Motivasi terhadap Kepuasan Kerja}

Motivasi tidak berpengaruh terhadap kinerja karyawan pada karyawan Icon Technology Lumajang, dikarenakan indikator motivasi seperti yang tercantum pada instrumen penelitian yaitu: Hubungan dengan rekan kerja dan atasan, Lingkungan kerja, Kesempatan meningkatkan pengetahuan dan keterampilan dan Pemberian Tunjangan. Perubahan motivasi memberikan efek yang kurang berarti terhadap kepuasan kerja karyawan. Selain itu menurunnya kepuasan kerja disebabkan oleh pembawaan manusia yang selalu mengikuti dan mudah dipengaruhi oleh 
lingkungan dan suka terhanyut oleh situasi dimana ia berada. Sehingga motivasi yang diberikan oleh seorang pemimpin kurang maksimal.

Dari pernyataan tersebut terbukti bahwa tinggi rendahnya motivasi pada karyawan Icon Technology Lumajang tidak mempengaruhi tingkat kepuasan kerja keryawan, karena di Icon Technology Lumajang sudah terjalin hubungan kekeluargaan antar karyawan dan telah menerapkan misi kedua yaitu meningkatkan kerja sama antar karyawan tanpa membedakan divisi.

\section{Pengaruh Kepeimpinan dan Motivasi Secara Simultan Signifikan terhadap Kepuasan Kerja}

Kepemimpinan dan motivasi secara simultan mempengaruhi meningkatnya kepuasan kerja karyawan Icon Technology Lumajang. Hal ini memang benar, karena ketika karyawan memiliki rasa puas yang tinggi terhadap pekerjaannya dan disertai kepemimpinan dengan kepemimpinan yang baik serta motivasi kepemimpinan yang baik pula maka secara otomatis mereka akan puas terhadap pekerjaannya. Dalam hal ini tentu dibutuhkan pemimpin yang baik, supaya bisa menjadikan karyawannya merasa puas dan berkomitmen untuk organisasinya, karena pada hakekatnya pemimpin yang dapat memotivasi karyawan itu yang sangat diperlukan untuk memuaskan karyawan dalam bekerja.

Dari pendapat di atas dapat ditarik kesimpulan bahwa semakin tinggi tingkat kepuasan kerja dan komitmen organisasi yang dimiliki karyawan, maka semakin tinggi pula tingkat OCB (Organizational Citizenship Behavior) yang tercipta.

\section{PENUTUP}

\section{Simpulan}

Berdasarkan analisis dan pembahasan hasil penelitian dengan melakukan pengujian hipotesis menggunakan analisi regresi linier berganda, dapat diambil kesimpulan sebagai berikut :

1. Secara parsial kepemimpinan berpengaruh terhadap kepuasan kerja pegawai. Sedangkan motivasi tidak berpengaruh terhadap kepuasan kerja pegawai. Tidak berpengaruhnya motivasi terhadap kepuasan kerja pegawai, dikarenakan faktor yang mempengaruhi motivasi diantaranya kemungkinan untuk berkembang itu kurang, hal ini disebabkan pegawai yang ada di Icon merupakan pegawai yang handal sesuai dengan bidangnya sehingga kemauan utntuk maju kurang.

2. Secara simultan hasil penelitian menunjukkan ada pengaruh yang signifikan antara kepemimpinan dan motivasi terhadap kepuasan kerja. Sedangkan nilai R Square sebesar 0.33 atau $33 \%$ menunjukkan bahwa kontribusi pengaruh kepemimpinan dan motivasi terhadap kepuasan kerja sebesar 33\% dan sisanya sebesar $67 \%$ dipengaruhi oleh variable lain yang tidak dimasukkan dalam penelitian ini.

\section{Saran}

Berkaitan dengan penelitian ini penulis menyarankan beberapa hal sebagai berikut :

1. Bagi Icon Technology

Disarankan agar pemimpin dapat mempertahankan sikap dalam memimpin pegawainya, dikarenakan sikap dan kepemimpinan tersebut dapat meningkatkan kepuasan kerja pegawai. Sedangkan pemimpin masih kurang memotivasi pegawai, sehingga kepuasan kerja dapat tercapai dengan baik.

2. Bagi Peneliti Lain 
Diharapkan bagi peneliti selanjutnya lebih memperluas dan mengembangkan penelitian yang telah dilakukan ini, peneliti lain dapat melengkapi dengan variabel independen dan dependen lain yang belum diangkat oleh peneliti dahulu agar hasil tersebut mempunyai perkembangan yang semakin sempurna.

\section{DAFTAR RUJUKAN}

Anoraga, Pandji.2003. Psikologi Kepemimpinan. Jakarta: Rineka Cipta

As'ad, Moh, 2004. Psikologi Industri: Seri ilmu Sumber Daya Manusia, Penerbit Liberty, Yogyakarta.

Handoko, T. Hani. 2003. Manajemen Edisi 2. BPFE. Yogyakarta.

Hastono, Sutanto Priyo. (2007). Modul Analisis Data. Fakultas Kesehatan Masyarakat Universitas Indonesia.

Kartono, Kartini, 2008 : Pemimpin dan Kepemimpinan. Jakarta : PT. Raja Grafindo Persada.

Robbins, 2003. Essentials of Organizational Behavior (Terjemahan), Edisi Kelima, Penerbit Erlangga ; Jakarta.

Robbins, P. Stephen dan Mary Coulter. 2014. Manajemen. Twelfth Edition. United States: Pearson Education Limited.

Slamet, 2007. Kiat Meningkatkan Kinerja, Cetakan Pertama. PT. Rineka Cipta ; Jakarta.

Sugiyono. 2013. Metode Penelitian Pendidikan Pendekatan Kuantitatif, Kualitatif, dan R\&D. Bandung: Alfabeta.

Sugiyono. 2015. Metode Penelitian \& PengembanganReseach and Development: Bandung. Alfabeta,cv.

Wahjosumidjo. 1991. Kepemimpinan yang Efektif. Yogyakarta: Balai Pustaka.

Wibowo, Fahmi Aji. 2013. Pengaruh Kepemimpinan dan Motivasi Terhadap Kinerja Karyawan Bagian Produksi Pada PT. Sari Tembakau Harum Kabupaten Kendal.

(http://lib.unnes.ac.id/18018/1/7350407006.pdf), 10 April 2017, 23:55. 